Article

\title{
Children's Participation: Questioning Competence and Competencies?
}

\author{
Carine Le Borgne * and E. Kay M. Tisdall \\ School of Social and Political Science, University of Edinburgh, Edinburgh, EH8 9LD, UK; \\ E-Mails: leborgnecarine22@gmail.com (C.L.B.), k.tisdall@ed.ac.uk (E.K.M.T.) \\ * Corresponding author
}

Submitted: 28 March 2017 | Accepted: 12 July 2017 | Published: 26 September 2017

\begin{abstract}
While Article 12 of the Convention on the Rights of the Child has encouraged children's ${ }^{1}$ participation in collective decision-making, the literature is replete with the challenges as well as successes of such participation. One challenge is adults' perceptions of children's competence and competencies. These are frequently used as threshold criteria, so that children viewed as incompetent or lacking competencies are not allowed or supported to participate. Despite this casual elision between children's participation and their (perceived) competence and competencies, the latter are rarely explicitly defined, theorised or evidenced. This article draws on research undertaken in Tamil Nadu (South India) and Scotland (UK), with two non-governmental organisations supporting children's participation in their communities. The article examines how staff members can validate and enhance children's competence and competencies, by scaffolding children to influence decision-making and recognising and adding to children's knowledge. These empirical findings suggest the need for increased scrutiny of the concepts of competence and competencies, recognising their disempowering potential. The findings argue that competence is situationally and socially constructed rather than a set and individual characteristic.
\end{abstract}

\section{Keywords}

adults; children; community; competence; competencies; family; participation; school; social competence

\section{Issue}

This article is part of the issue "Promoting Children's Participation in Research, Policy and Practice", edited by Jo Aldridge (Loughborough University, UK).

(C) 2017 by the authors; licensee Cogitatio (Lisbon, Portugal). This article is licensed under a Creative Commons Attribution 4.0 International License (CC BY).

\section{Introduction}

Article 12 of the UN Convention on the Rights of the Child (CRC) recognises children's human right to participate in decisions that affect them. We now have documented successes, where children's views have helped shaped decisions about their own lives - for example, in family courts (Birnbaum \& Saini, 2012)-and for their communitiesfor example, in influencing local budgeting (Pereznieto, Powell, \& Avdagic, 2011) and addressing the marriage of young girls (Bandyopadhyay, 2015). Despite these successes, children's participation is still too often not effective, meaningful nor sustainable. How can we capitalise on the successes of children's participation and address the challenges too often experienced by children?
Adults-whether as parents, professionals or policy decision-makers - retain considerable control over what 'counts' as children's participation: about which children should be heard, when, on what topic, and to what effect (Percy-Smith \& Thomas, 2010). Throughout the literature and in practice, adults' ideas of children's competence or incompetence, competencies or the lack of competencies, continue to influence whether children are involved or not in decisions that affect them (Fortin, 2009; Tisdall, in press). Yet these terms are contested in themselves, rarely defined and duly considered in practice, and their relationships with children's participation assumed but underexplored (Ljungdalh, 2012).

This article seeks to explore the relationships between competence, competencies and participation for

\footnotetext{
${ }^{1}$ The article broadly refers to 'children' as defined by Article 1 of the United Nations Convention on the Rights of the Child. This refers to children up to the age of 18 , unless legal majority is obtained earlier.
} 
children. First it does so in light of children's participation rights in the CRC and related literature, to explore how the concepts are used and the questions that arise. Second, the article draws on empirical findings from research undertaken in Tamil Nadu (South India) and Scotland (UK), with two non-governmental organisations (NGOs) supporting children's participation in their communities. The analysis shows how staff members can validate and enhance children's competence and competencies, by scaffolding children to influence decision-making and recognising and adding to children's knowledge.

\section{Participation, Competence and Competencies}

The nearly world-wide ratification of the CRC has galvanised attention to children's human rights-and particularly children's rights to participation. The most referred to participation right is Article 12, recognised as a general principle of the CRC (UN Committee on the Rights of the Child, 2003):

States Parties shall assure to the child who is capable of forming his or her own views the right to express those views freely in all matters affecting the child, the views of the child being given due weight in accordance with the age and maturity of the child. (Article 12(1))

The UN Committee on the Rights of the Child published a General Comment on Article 12, in 2009, which recognises the growing activities at local, national, regional and global levels to promote the implementation of Article 12 (para. 3). At the same time, the UN Committee note continued impediments to children's participation, in terms of 'long-standing practices and attitudes, as well as political and economic barriers' (para. 4) and was 'concerned about the quality of many of the practices that do exist' (para. 5). Fully realising children's rights to participate, then, remains problematic in too many contexts.

The realisation of children's participation rights remains highly dependent on adults, who in one way or another hold powerful positions such as legal guardians of children, administrative or political decision-makers, or front-line professionals. The attitudes of such adults toward children and childhood strongly influence whether or not the adults recognise, facilitate and support children's participation (Mayall, 2006). One of the most persistent adult concerns is whether children are competent enough to participate. Competency is frequently used as a threshold criterion, so that children who are considered incompetent are not allowed or not supported to participate. Hinton (2008) refers to this as the 'competence bias'. Adults perceive children as having limited or lesser competence than adults, with the concentration on children's lack of competence to participate rather than adults' lack of competence in enabling children to participate.

Despite the frequent use of competence within discussions of children's participation rights (e.g., Hart,
1997; UN Committee on the Rights of the Child, 2009), the terms are rarely explicitly defined or debated (Fortin, 2009). For example, Ljungdalh (2012) undertook a review of child and youth research, finding that competence is rarely defined nor is its relationship to participation clear on its causality (does competence lead to participation or participation lead to competence?). His analysis shows a complex and complicated use of competence, without consensus on definitions nor the relationships between competence and participation.

This complexity may in part be due to the increased interest internationally on competence within education and amongst professionals (e.g. see Ananiadou \& Claro, 2009; Bjarnadóttir, 2004). In a review of professional competence for nursing, for example, Schroeter (2008) notes the many descriptors of competence. She distinguishes between competence as 'a potential ability and/or capability to function' (p. 1) in a given situation and competency as 'one's actual performance in a situation' (p. 2). Competency, then, is more than knowledge and skills but the actual application and demonstration of them. Hutchby and Moran-Ellis (1998) use the term 'social competence' to capture the relationality of competence: people express competence socially and in situ. Social competence is not necessarily achieved easily nor straightforwardly but can involve 'struggles for power, contested meanings and negotiated relationships' (Hutchby \& Moran-Ellis, 1998, p. 16). Thus powerand particularly the power of adults-is key to children's practical achievement of competency.

This overview suggests that the 'competence bias' continues to have a strong grip-and often a constraining one-on the recognition and realisation of children's participation rights. The developmental paradigm, which emphasises children as having evolving capacities and presuming incapacity in comparison to adults (Lansdown, 2005), can be used to exclude children from participation. Children's exclusion is furthered when competence is presumed to be individualised and intrinsic, rather than recognising competency as enacted and relational. The individual assignation of incompetence to children reduces children's opportunities to participate, putting them in a less powerful position than those adults assumed to be competent. The 'competence bias' is thus associated with intergenerational hierarchies of power. It is the adults' power to ascribe incompetence to children, which prevents children's expression of social competence. Rights are arguably particularly important to recognise then, as a remedy to powerlessness, flowing downhill to the least powerful (Federle, 1994, 1995).

Below, we trace through research evidence from local participation projects showing the continuing power of the competence bias-and how staff members can validate and enhance children's competence and competencies and thus recognise children's participation rights. First, an overview of the research methods and the participation projects is provided, before considering the interplay between participation and competence 
for children in the contexts of their communities, schools and families.

\section{Methods}

Research was undertaken in Tamil Nadu (South India) and Scotland (UK) to address how NGOs involve children in making decisions about their local communities. The study was exploratory, considering what enabled and inhibited the processes of children's participation within the two cases.

To answer the research questions, a qualitative case study approach was chosen. This approach provided opportunities for in-depth study of the actors' (children and adults) views and their opinions in an effort to better understand the implementation of children's participation in a real-life context (Yin, 2009). Yin's (1993) and Stake's (1994) typologies were useful to clarify that the research was using a case study approach to consider cause and effect relationships. The purpose of the research design was not to generalise findings to other cases, but to explore themes, connections, and patterns relating to the implementation of children's participation in two specific contexts. Such explorations have theoretical generalisability and, as such, implications for policy and practice (Luker, 2008).

Amongst other criteria, the chosen NGOs were selected because they had more than ten years of experience in delivering children's participation projects and implemented projects in the local community where children could influence decision-making about their lives. To realise children's participation, the NGO in Tamil Nadu primarily used two processes-participation workers supported children to organise and submit petitions to local decision makers and to undertake letter writing campaigns. In Scotland, the NGO worked closely with a group of children over several months, on a photography project. The two contrasting contexts (Tamil Nadu and Scotland) allowed children's participation to be considered in majority and minority ${ }^{2}$ world settings; such cross-contextual research is lacking in childhood studies (Punch, 2015). This is not to erase the considerable differences-from socio-economic to cultural-between these two places-but to use such differences as resources, to question taken-for-granted assumptions and to develop new ideas (see also Crowley, 2012; Johnson, 2010) on how NGOs can support children's participation.

Both case studies involved observations, informal discussions and semi-structured interviews with children aged 13 to 16 years old and staff members from the NGOs. In total, 48 participants took part in the research project. The observations focused on staff meetings and meetings with children as well as children's activities: for example, capacity-building workshops in
Tamil Nadu or children delivering workshops Scotland. For the Tamil Nadu case study, the researcher was accompanied by an interpreter. The semi-structured interviews with 33 children and 15 staff members touched on various topics, including: understanding of children's participation, challenges and the lessons learned from the children's participation project. Relevant documents were obtained and scrutinised during the observation phase to give a broader understanding of the NGO work. These helped to create follow-up questions for the semistructured interviews.

Thematic analysis was used to identify themes and patterns of meaning across and within the data, in relation to the research questions (Braun \& Clarke, 2013). The analysis was both inductive and deductive. A withincase and cross-case synthesis (a matrix in a Microsoft Word document) was developed and then used to compare analytical categories across the two case studies. The cross-case analysis established "patterns of association within cases that hold true across cases, without losing sights of the particularities of each case" (Bazeley, 2013, p. 285). Moreover, the qualitative data from different sources (children, staff members) and the method of data collection (observation notes, semi-structured interviews, and documents) were triangulated. Triangulation recognised multiple perspectives on the cases, facilitating the comparison of perspectives and identifying similarities and differences. Triangulation was used to confirm (or contradict) patterns in the research (Fielding \& Fielding, 1986).

Due to the nature of the research in development work, as a white person from the minority world, the researcher was positioned as an 'outsider', as someone with resources or as a potential funder. However, the researcher was already familiar with the Tamil Nadu context due to her work experience, so the living conditions were not a surprise, and she was familiar with the language and local community. In some ways, she was more of an outsider in the Scottish context because she had no similar work experience to draw upon. However, in both contexts she was a 'foreigner' due to her language and French origins.

Ethics were considered throughout the entire research project (Kvale, 2007, p. 24). The research gained ethical approval from the School of Social \& Political Science's Research and Ethics Committee, at the University of Edinburgh. The research team considered a range of ethical issues throughout, from participant recruitment to data management to feedback to participants. Four issues required particular consideration. First, informed and on-going consent needed to be negotiated with research participants. This included ensuring that information was accessible, translated into suitable languages and explained in writing and verbally. The research team

\footnotetext{
$\overline{2}$ The terms 'majority world' and 'minority world' refer to what have traditionally been known as the 'Third and First worlds' respectively or more recently as the 'Global South' and the 'Global North'. The terms acknowledge that the 'majority' of the population, poverty, land mass and lifestyles is located in the former, which comprises countries in Africa, Asia and Latin America, and thus seeks to shift Western perceptions that frequently highlight the importance of 'Western' and 'Northern' populations and issues (Punch, 2003).
} 
anticipated that written consent forms could be inappropriate to the Tamil Nadu case study, due to literacy issues and political concerns about signing written statements. However, written consent was regularly used by the NGO and thus participants were familiar and comfortable to provide consent in this way. Second, comfortable and culturally appropriate spaces for children were needed for their interviews. The interviews took place in the field office of the NGO. Third, all participants were informed of an exception to confidentiality, should the researcher become aware of the participant or someone else being at risk of significant harm. This exception was addressed in the initial research consent with potential participants. Each NGO had an established protocol with how to deal with such concerns, and an identified person to whom the research team could go to with any concerns. No such concerns were identified during the research. Fourth, confidentiality needed to be considered carefully, in at least two ways. An interpreter was needed for the Tamil Nadu case study for the Tamil Nadu interviews and fieldwork observation. The interpreter was fully briefed about the research in advance, including confidentiality, as part of their recruitment. Care was taken to consider confidentiality between respondents, in a case. This became an issue in the group discussion with participation workers, resulting in a decision not to continue with that discussion but to have individual interviews so workers could speak more freely. Further, in presenting the findings specific staff positions are not identified, to protect participants' anonymity; instead, broader categories are used of 'participation workers' and 'management team' in Tamil and 'staff' due to the small numbers of workers and lack of hierarchy in the Scottish NGO. More information on the methodology and the ethical considerations can be found in Le Borgne (2016).

The analysis identified that perceptions of children's competence and competencies were both facilitators and inhibitors of children's participation. Below, these findings are drawn out for the three contexts discussed by children: their communities, their families and their schools.

\section{Children's Competence and Competencies in Their Communities}

Adults' perceptions of children's competence and competencies made a considerable difference to the extent that children's participation activities influenced decisions in their communities.

In the Tamil Nadu case study, Aya (management team) described community perceptions of children: adults were considered supreme, whereas children were subordinate. Thus, children's ability to express their competencies was impeded. However, the NGO project was able to ease such impediments, by facilitating children to use processes available to all adults in the community to influence change. One such process was petitioning local decision-makers. A typical example is given by Kathira
(16 years old), who spoke proudly of herself and other children writing a petition and meeting the local authority officer through the help of the project's participation workers. The children were able to persuade the local authority to build toilets and provide access to drinking water in the slum area where they lived. Kathira's example illustrates how children, as a collective, were supported by the NGO to express their competency.

When children express their competency, it can change adults' views. Dahma (management team) described a dramatic example in which children were able to organise for a temple to be built, when adult community members had failed to do so. Dahma herself had thought the children were being too ambitious. But she supported the children when they insisted and project participation workers helped them set up a meeting with the community leader. Following the meeting, the children helped the community leader raise the required donations to complete the temple, which in due course was finished. According to Dahma, this success was highly approved of by the community and improved adults' recognition of both the project and the children's competence. Children themselves were able to shift adults' perceptions - this applied to Dahma herself, to the community leader and eventually the wider community. The example shows that adults' judgements of children's competences are still decisive because adults had the power to decide whether or not to support children to participate and whether or not to interact with them (see Bacon \& Frankel, 2014). Once again, the NGO was an important lever to facilitating (or not) children's participation, which in turn led to positive changes in their community.

In the Scottish case study, Martin (staff) explained that the photography project enabled children to develop their ideas about how to improve their community. The project captured the participants' perspectiveswho they were and where they lived-via a photo exhibition and a published book. The book analysis revealed that children took pictures of problematic issues in their communities, such as the negative use of graffiti. A photo exhibition was organised for decision-makers, parents and other professionals working with children in the council. However, no visible changes in the community were identified after the exhibition, according to research participants. In comparison to the Tamil Nadu examples, the exhibition and book were not directly confrontational nor explicit on the changes requested by the children in their communities. The Scottish case study ably demonstrated children's competency, in making the book and holding the photography exhibition. But children's participation did not lead to noticeable change in their local community. The Scottish case study did not demand a substantial change in power relations nor particular negotiations with adult decision-makers.

Power and negotiation are integral to understanding social competence (Hutchby \& Moran-Ellis, 1998). In the Tamil Nadu case study, children expressed their com- 
petencies through negotiating and claiming their rights from, and in engaging in meaningful social action with, adults at the community level. The Tamil Nadu case exemplifies how participatory community projects can constructively change adult-child relations over time; this is important, particularly as children develop their own interpersonal skills and engage in ongoing dialogue with adults in their communities (Ackermann, Feeny, Hart, \& Newman, 2003, p. 27; Johnson, 2017). However, in Scotland, where the children did not have a formal mechanism to influence decision-making, competence was emphasised by staff but their competency was limited in influencing community change.

\section{Can Children's Competence and Competencies Be Transferred to Schools?}

The participation projects helped children to demonstrate their competencies in school-related contexts. Children were able to transfer their competence and competencies to their school contexts but had far more difficulty in influencing change in schools themselves.

In the Tamil Nadu case study, Sasiva (15 years old) was president of her children's group in the NGO. Sasiva reported how her leadership skills became recognised in the school, when she was asked to assist the teacher in a mathematics class and she was appointed captain of the volleyball team. Sasiva herself felt she had transferred her increased competence in leadership to the school context. Her school teachers appreciated the NGO's work, recognised Sasiva's increased competence, and Sasiva was able to show her social competence within the school context. Equally, children in the Scottish case study were able to transfer their skills and knowledge to school. For instance, Olivia (14 years old) shared that, because she had been to the Scottish Parliament with the NGO, she was able to use that knowledge in class. She realised that she knew quite a lot compared to other students who had not been involved with the NGO, illustrating that Olivia gained specific knowledge by being part of the participation project, and that she was able to use it in the classroom context. Both case studies demonstrate that competences acquired in the NGO projects were used in the school context.

However, in the Tamil Nadu case study, the school context did not encourage children to demonstrate their competency by taking concrete action to influence change. This is illustrated by an unusual example-when the children did not follow the usual participation process. Three members ( 15 years old) created a petition to appoint a new teacher-to address their concern about the lack of teaching staff-directed to the Chief Education Officer. The children did so without informing their parents or NGO staff members. The Chief Education Officer was extremely angry when he received the petition because the children came on their own. He threatened not to allow the children to complete their exams. The children informed the NGO staff members about this in- cident. The staff members then spoke with the children's parents and sent a letter to the Officer explaining that the children had gone to the City Municipal Corporation with the parents' approval. Both problems were solved: the children were able to take their exams and also secured a new teacher. However, without the mediation of staff members (and ultimately parental approval), the children would have been blocked from claiming their rights and, further, been punished by not being able to take their exams. The adults' perception of children's competence and competency did not change throughout this example. Children's competence and competency alone were considered threatening and unpersuasive to the Chief Education Officer. The children's demands needed to be validated by the NGO and their parents, which led to the ultimately positive outcomes. The question is not then about whether competent individuals are powerful or powerless; the pertinent questions are whether decision-makers ascribe competence to people and allow for the spaces for their competency to be expressed.

In the Scottish case study, limited spaces were identified for children to express their competency. Some of the children interviewed had attended their school's pupil council-where children gather to discuss schoolwide issues and potential improvements (Cross, Hulme \& McKinney, 2014)-without effect. Annabel's (16 years old) experience was similar to others in the case study:

I went a couple of times, but I did not really enjoy it. I am not saying that it's a bad thing but they are trying to act like we are making decisions...but they are doing what they wanted to do in the first place.... I don't want to waste my time..... prefer to go and have my lunch. They will make the final decision anyway.

Her example shows that little negotiation was possible, as the decisions had already been made and there was therefore no space to include children's contributions. From fieldwork observations, the school knew which children had been part of the NGO activity but Annabel's example shows how her competence to participate was not realised in the school context. In the school council, power relationships were already well established and children had limited opportunities to influence change.

In both case studies, children were able to transfer certain competences to the school context, especially when competences were individualised, such as leadership skills or knowledge. However, when children wanted to express these competencies to influence school decision-making, they were confronted with resistance by certain adults. In both case studies, particular competencies were not welcome in the school context and children were stopped from achieving their desired results. In Tamil Nadu, children had to ensure parental approval and staff support before their social competence was recognised. Children's ability to navigate this situation shows competency in itself, embedded in the con- 
tinued influence of the competence bias amongst certain adults.

\section{Can Children's Competence and Competencies Be Transferred to Their Families?}

As with schools, children in the study reported how they transferred competence from the NGO projects to their family contexts. Such a transfer was more evident in the Tamil Nadu case study than in the Scottish one.

In the Tamil Nadu case study, children gave numerous examples of family members' increasingly recognising the competences-and particularly knowledgethey had gained through their participation in the NGO. Sasiva (15 years old) gave an extensive example. When her father was sick, her mother asked Sasiva if she knew which hospital would admit him. Sasiva had learned this information from her NGO children's meetings and was able to inform her mother of what to do. Sasiva's mother now saw Sasiva as a useful source of knowledge on her community. Similarly, in the Scottish case study, some children said that their parents started seeing them as highly knowledgeable. A typical example was given by Olivia (14 years old): 'We always have discussion and debate, I say [name of the organisation] told me this and that and they say "we are listening to an expert". Olivia was able to bring her knowledge into family discussions at home thanks to what she learned from the NGO. These two examples show that children thought parents changed and recognised the children's competence due to children's involvement in the participation projects, particularly in terms of children having increased knowledge and the competency to contribute this meaningfully.

The importance of the NGO link was very evident in how former child workers were able to influence their parents in the Tamil Nadu case study. A number of children who had been involved in domestic work used the power from being involved in the NGO, and the power of the NGO staff itself, to influence their parents' decision about the children working. Maalni (15 years old) explicitly used the NGO's power to support her wish not to work. She told her mother that if she went to work instead of attending school, NGO staff members would go to the house where both she and her mother worked and imprison their employers, and fine Maalni's mother for sending her child to work. After that, Maalni's mother told her that Maalni did not need to go to work, illustrating that Maalni was able to influence decision-making in the family context by using legal arguments such as the risk of a fine and imprisonment. Maalni's example demonstrates how she influenced decision-making processes by mentioning the knowledge and authority of NGO staff members and other adults in her negotiations.

Children in the Scottish case study identified fewer influences on 'major' decisions within their families. Participation in the NGO project did not necessarily transfer to children thinking they should be able to influence such decisions, either because the decisions were too important (e.g. financial) or too complicated to negotiate collectively (e.g. family outings). Children did say they influenced 'minor' decisions about their own appearance, bedrooms or dinner. Children's competence to participate was less easy to transfer into their family lives (see also Horgan, Forde, Parkes, \& Martin, 2015).

Thus, the family contexts remained the most difficult for children to express their competency. Their competence was acknowledged, in several situations, in families-particularly in relation to children's knowledge gained through their participation activities. But this did not necessarily transfer to 'major' decisions such as whether children would work or financial decisions in families. In Tamil Nadu, this is highlighted by children needing to refer to the legal and informational authority of their NGO project. While children had felt this appeal was necessary, their social competence in doing so was ultimately highly successful in their views being heard and decisive. In a more subtle way, children's competence in Scotland also gained recognition because of its link to the NGO. Once again, we see how children were able to use the NGOs to leverage greater social competence.

\section{Conclusion}

The research evidence underlines that children's competence and competency are not intrinsic and individual characteristics but situated and relational. This is evident when contexts and relationships either supported or limited children's abilities to influence decision-making; it is evident when children reported their varied influences across community, school and family decision-making. The findings thus support a relational approach to children's agency (Leonard, 2015; Punch, 2016). For Leonard (2015), the concept of agency recognises children as actively constructing their own childhoods but she argues that children's agency must be located within the positioning of childhood relative to adulthood. She advocates considering how children and adults relate to one another, to understand the opportunities and constraints under which children practise agency and, thus, can be considered as agentic. For her, their agency emerges from and operates within generational relationships.

Both NGOs in Tamil Nadu and Scotland were seeking to support children to influence community change intergenerationally. The differences between the case studies illuminate how social competence is expressed socially and in situ. Children's competency was better achieved in the Tamil Nadu case study compared to the Scottish one, with the former's more direct and often confrontational participation approach directly linking children to community decision-makers (whether the community leader, the local decision-maker, or the Chief Education Officer). In the Scottish case study, children had less opportunity to demonstrate their social competences because the photographic exhibition did not provide a vehicle for 
them to negotiate directly with adult decision-makers. The Tamil Nadu case study was more tightly linked to decision-makers, than the Scottish case study was, and more immediate impact was evident in the Tamil Nadu case study.

The 'competence bias' continued to influence children's expression of competency. When adults perceived children as competent, children's competencies were enhanced. This is evidenced within the NGOs, where staff members in both projects helped develop children's competences and encouraging their expression of competencies. When parents recognised children's knowledge, gained through the NGOs, the children gained recognition for their (increased) competence. The examples given above show the constraining perceptions of children's competence of several key adult decision-makers, in Tamil Nadu, which limited children's participation. The examples also show how the bridging by NGO staff members helped ameliorate or even change such limiting perceptions.

The research particularly brings out the key role of NGO staff members in children's social competence. The NGO activities in this research increased children's knowledge, which they not only used in their communities but were able to transfer to their school and family contexts. The NGO staff members were key to providing the link between children and adult decision-makers in their communities: this was done successfully in Tamil Nadu and less successfully in Scotland. Children's use of the legal and information authority of the Tamil Nadu NGO was striking, when they were ultimately able to gain a new teacher and avoid punishment, and in negotiating with their parents not to work. These examples also brought out that children were limited in expressing their social competence, without the NGO support.

This leads to two conclusions. First, strengthening the role of the staff members in children's participation is worthwhile (Johnson, 2017; Le Borgne, 2017) because they can play key roles in developing and validating children's competence and enhancing children's competencies. Staff's own perceptions of children's competences and competencies influence how well they support children and children's influence on decision-making.

Second, the competence bias remains pernicious and often unhelpful to children's participation. The bias can mean that participation workers, as key intermediaries, may be necessary to facilitate children's participation rights. But it may mean that children's competences are under-recognised. The children who petitioned for a new teacher had the competencies, but their context did not allow them to demonstrate those competencies. It required a change in the context-the intervention of the NGO-for children's social competence to be achieved. This change had the positive effect of ensuring children's views were heard. But it undermined children's recognition, because they could only achieve this through 'borrowing' parental and NGO power and not in their own right. Thus intermediaries, like NGOs, can provide vital roles to ensuring children's participation rights are realised. However, if it were accepted that children always should have intermediaries (Gibbons, 2015; Nguyen, 2013), the competence bias of adult decisionmakers can remain unchallenged. With the fixation on children having evolving capacities (as if adults are not also constantly evolving in their capacities?), there is always a risk of children needing to prove their competence or to meet some unexplained and unevidenced threshold to be considered competent. Instead, we could consider competence and competency far less relevant to children's involvement in decisions about their communities and concentrate far more on how all community members have potential knowledge, experiences, and expertise they can contribute.

\section{Acknowledgements}

Carine Le Borgne specially thanks to: two NGOs, one in Tamil Nadu, India, and the other in Scotland, UK (which cannot be named for ethical reasons), that assisted with this research; the children and staff members who gave their time generously, along with their valuable insights and cherished experiences; and interpreters in Tamil Nadu. Additional thanks are given to her two supervisors, Professor Kay Tisdall and Professor Patricia Jeffery for their support, helpful discussion, encouragement, inspiration to guide her through this process of the PhD. Kay Tisdall acknowledges a range of collaborative projects funded by the Big Lottery Fund, the British Academy, Economic and Social Research Council (R451265206, RES-189-25-0174, RES-451-26-0685) and Knowledge Exchange funds from the University of Edinburgh and the ESRC Impact Acceleration Account, the European Research Council, the Foundation of Canadian Studies, the Leverhulme Trust, the Royal Society of Edinburgh and the Social Sciences and Humanities Research Council of Canada. We appreciate the detailed comments from anonymous reviewers of the draft article.

\section{Conflict of Interests}

The authors declare no conflict of interests.

\section{References}

Ackermann, L., Feeny, T., Hart, J., \& Newman, J. (2003). Understanding and evaluating children's participation. London: Plan International.

Ananiadou, K., \& Claro, M. (2009). 21st century skills and competences for new millennium learners in OECD countries (EDU Working Paper no. 41). Paris: OECD.

Bacon, K. V., \& Frankel, S. (2014). Rethinking children's citizenship: Negotiating structure, shaping meanings. International Journal of Children's Rights, 22(1), 21-42.

Bandyopadhyay, D. (2015). How rural girls are standing up to child marriage in India. Girls not Brides. 
Retrieved from http://www.girlsnotbrides.org/howrural-girls-are-standing-up-to-child-marriage-in-india

Bazeley, P. (2013). Qualitative data analysis: Practical strategies. London: Sage.

Birnbaum, R., \& Saini, M. (2012). A scoping review of qualitative studies on the voice of the child in child custody disputes. Childhood, 20(2), 260-282.

Bjarnadóttir, R. (2004). "Modern adolescents" leisure activities: A new field for education? Young Nordic Journal of Youth Research, 12(4), 299-315.

Braun, V., \& Clarke, V. (2013). Successful qualitative research, a practical guide for beginners. London: Sage.

Cross, B., Hulme, M., \& McKinney, S. (2014). The last place to look: The place of pupil councils within citizen participation in Scottish schools. Oxford Review of Education, 40(5), 628-664.

Crowley, A. (2012). Is anyone listening? The impact of children's participation on public policy (Doctoral dissertation). Cardiff School of Social Sciences.

Federle, K. H. (1994). The violence of paternalism. Wake Forest Law Review, 49(3), 703-712.

Federle, K. H. (1995). Rights flow downhill. International Journal of Children's Rights, 2(4), 343-368.

Fielding, N., \& Fielding, J. (1986). Linking data. Beverly Hills and London: Sage.

Fortin, J. (2009). Children's rights and the developing law (3rd ed.). Cambridge: Cambridge University Press.

Gibbons, E. D. (2015). Accountability for children's rights. Retrieved from http://www.unicef.org/policy analysis/rights/files/Accountability-for-Childrens-Rig hts-UNICEF.pdf

Hart, R. (1997). Children's participation. London: Routledge.

Hinton, R. (2008). Children's participation and good governance: Limitations of the theoretical literature. International Journal of Children's Rights, 16(3), 285-300.

Horgan, D., Forde, C., Parkes, A., \& Martin, S. (2015). Children and young people's experiences of participation in decision-making at home, in schools and in their communities. Dublin: Department of Children and Youth Affairs.

Hutchby, I., \& Moran-Ellis, J. (1998). Children and social competence: Arenas of action. London: Falmer Press.

Johnson, V. (2010). Changing contexts of children and young people's participation in evaluation: Case Studies in Nepal and the UK (Doctoral dissertation). University of Central Lancashire.

Johnson, V. (2017). Moving beyond voice in children and young people's participation. Action Research, 15(5), 104-124.

Kvale, S. (2007). Doing interviews. The Sage qualitative research kit. London: Sage.

Lansdown, G. (2005). The evolving capacities of the child. Florence: UNICEF Innocenti Research Centre.

Le Borgne, C. (2016). Implementing children's participation at the community level: The practices of nongovernmental organisations (Doctoral dissertation). University of Edinburgh.
Le Borgne, C. (2017). Implementing children and young people's participation in decision-making at the community level: the practices of non-governmental organisations. Retrieved from https://www.era.lib.ed. ac.uk/bitstream/handle/1842/21025/CRFR\%20Brief ing\%2087.pdf?sequence $=1$ \&isAllowed $=y$

Leonard, M. (2015). The sociology of children, childhood and generation. London: Sage.

Ljungdalh, A. K. (2012). Mapping and reviewing concepts of children's and young peoples' competence, participation and competence development. Retrieved from http://pure.au.dk/portal/files/51513337/Rep ort_no_1_ccypcc_project_BUK_DPU_29_11_12.pdf

Luker, K. (2008). Salsa dancing for the social sciences. Cambridge, MA: Harvard University Press.

Mayall, B. (2006). Child-adult relations in social space. In E. K. M. Tisdall, J. M. Davis, M. Hill \& A. Prout (Eds.), Children, young people and social inclusion (pp. 199216). Bristol: Policy Press.

Nguyen, L. T. P. (2013). Child-responsive accountability. Retrieved from http://www.unicef-irc.org/ publications/pdf/iwp_2013_16.pdf

Percy-Smith, B., \& Thomas, N. (2010). Conclusion. In B. Percy-Smith \& N. Thomas (Eds.), A handbook of children and young people's participation (pp. 356-366). London: Routledge.

Pereznieto, P., Powell, A. G., \& Avdagic, M. (2011). Investment in children. Report commissioned by Save the Children Child Rights Governance Initiative. London: Overseas Development Institute. Retrieved from https://www.savethechildren.net/sites/default/files/ libraries/Investment-in-children-FINAL-REPORT.pdf

Punch, S. (2003). Childhoods in the majority world: Miniature adults or tribal children? Sociology, 37(2), 277-295.

Punch, S. (2015). Possibilities for learning between childhoods and youth in the minority and majority worlds: Youth transitions as an example of cross-world dialogue. In J. Wyn \& H. Cahill (Eds,), Handbook of children and youth studies (pp. 689-701). Singapore: Springer.

Punch, S. (2016). Exploring children's agency across majority and minority world contexts. In F. Esser, M. Baader, T. Betz, \& E. Hungerland (Eds.), Reconceptualising agency and childhood: New perspectives in childhood studies (pp. 183-196). London: Routledge.

Schroeter, K. (2008). Competence literature review. Retrieved from http://www.innovationlabs.com/ research/pre/reading_materials/competence_lit_re view.pdf

Stake, R. E. (1994). Qualitative case studies. In N. K.Denzin \& Y. S: Lincoln (Eds.), The Sage handbook of qualitative research (pp. 236-247). Thousand Oaks, CA: Sage.

Tisdall, E. K. M. (in press). Challenging competency and capacity? Due weight to children's views in family law proceedings. International Journal of Children's Rights. 
UN Committee on the Rights of the Child. (2003). General Comment No.5: General measures of implementation of the Convention on the Rights of the Child ( $C R C / G C / 5)$. Geneva: United Nations.

UN Committee on the Rights of the Child. (2009). General Comment No. 12: The right of the child to be heard $(C R C / C / G C / 12)$. Geneva: United Nations.
Yin, R. K. (1993). Applications of case study research. London: Sage.

Yin, R. K. (2009). Case study research: Design and methods. London: Sage.

\section{About the Authors}

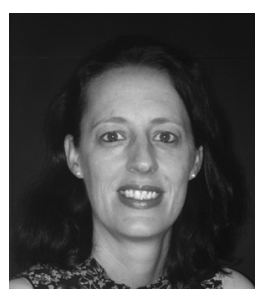

Carine Le Borgne (PhD) is an advocate for human children's rights and a researcher on operationalisation of children's participation at the community and national levels. Fifteen years of experience on non-profit sector with a focus on governance, programme and policy on children's rights in India, Philippines, Egypt, Chile, Canada, United Kingdom and France.

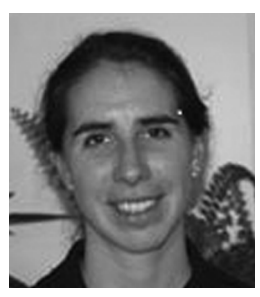

E. Kay M. Tisdall is Professor of Childhood Policy and Co-Director of the Centre for Research on Families and Relationships at the University of Edinburgh. She is Programme Director of the MSc in Childhood Studies. 